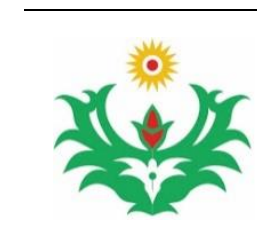

Linguistik Terapan 17 (2) (2020): 123-130

Jurnal Linguistik Terapan Pascasarjana

Available online

http://jurnal.unimed.ac.id/2020/index.php/JLT-Unimed

\title{
Subtitling Strategies Used in The Meg Movie Texts
}

\author{
Devi Suci Nirwana \\ Rahmad Husein \\ Zainuddin
}

English Applied Linguistics Program

Postgraduate Program-Universitas Negeri Medan

Diterima Mei 2020; Disetujui Juni 2020; Dipublikasikan Agustus 2020

\begin{abstract}
The objective of this study is to explain the reason of utilizing subtitling strategies in The Meg movie texts. The research methodology used in the research is qualitative research design. The data were analyzed by using interactive model of qualitative data management and analysis namely data collection, data condensation, data display and verification and conclusion. The findings of this study revealed that the reasons of translator used subtitling strategies in The Meg Movie Texts consisted of historical circumstances, traditions and the strategy to which is accustomed for both the source and the target viewer. The conclusion that the strategy to which is accustomed for both the source and the target viewer as the focused on translator reason used subtitling strategies in The Meg movie texts.
\end{abstract}

Keywords: Movie, Subtitles, Subtitling Strategies, Translation, Texts

How to Cite: Nirwana, Devi Suci (2019). Subtitling Strategies Used in The Meg Movie Texts. Jurnal Linguistik Terapan Pascasarjana Unimed, 17 (2): 123-130

ISSN: 2407 - 7410

\section{INTRODUCTION}

Catford in Machali (2000:5) states that translation is the replacement of textual material in one language (SL) by equivalent textual material in another language (TL). Translation is reproducing source language in equivalent way into target language as close as possible to the original one. Translation itself has always been a central part of the communication between two different languages. Subtitling as the rendering of the verbal 
message in filmic media in a different language, in the shape of one or more lines of written text, which are presented on the screen of the movie.

Gottlieb (1997) proposed that subtitling strategies used by subtitler in translating word, phrase or speaker's utterance in audiovisual field. Subtitle translation's aim is to translate a verbal language to written and to transfer the information to the viewers in a limited space. Unlike literally translation, a subtitler (person who translate subtitle) needs an excellent listening skill to translate. Therefore, subtitles can help the audiences learn the foreign language through a movie. There are many genre of movie can be chosen by the translator to translate the subtitle film.

The Meg movie is one of the famous movie in 2018 that enjoyed by all age circles, from children until adult and it is directed by Jon Turteltaub. This movie is about the shark namely Megalodon, the largest shark ever known believed to be extinct for millions of years. The source language (SL) of this movie is English and the target language (TL) is Indonesian. Rizal Adam as the movie subtitler applied many types of subtitling strategies in the subtitles so the viewers can be easily got the idea of each utterance in the movie.

In this case, the problems appear when the researcher saw some awkward cases in the TL. Not all of the SL translated fully in the TL, there are number of words in the SL less of the TL and vice versa.

The following are some preliminaries data found by the researcher by the data source is the subtitling of The Meg movie, such as:

Data 97

SL: Wow, look at that

TL: Wah, lihat itu

Data 102

SL: Blast

\section{TL: Ledakkan sekarang}

In the first example, the subtitler changed the word of Wow into Wah because adopted when the original employs some sort of special effect where the translation of the effect is more important than the content. It produces a different expression in the target text that adjusts the contents of the source text so that it conforms to the target text-language. It is used in connection with metaphorical phenomena. 
The last example, the subtitler has giving addition meaning in the target languages which is not existed in SL. The subtitler added the word of sekarang for emphasizing the TL itself.

This is not the first study in the academic world. There have been some previous studies conducted by several researchers related to this research. They are inspiring the researcher to do a further study about it. Related to this study, the researchers found some previous researchers in the journals either national or international which are related to the title that is going to be conducted. Some of them discussed about Subtitling Strategies and the others discussed about Interlingual Subtitling, Translation Strategies, Subtitle Translation and Strategies used by Subtitler.

Here are the more explanation about the previous studies that discussed about Subtitling Strategies used the theory presented by Haryanto's (2005:103) and another used the theory of Gottlieb's (1992:76). The previous study by Hastuti (2015) with a research an analysis on subtitling strategies of Romeo and Juliet Movie. The finding of this research is there are nine strategies that applied in Romeo and Juliet Movie are expansion, paraphrase, transfer, imitation, condensation, decimation, deletion, taming, and resignation. The most dominant strategy that used in those movie is condensation. And there accuracy of the subtitling in Romeo and Juliet Movie hang on context covering from the text, situation context or cultural context. The next previous study by Kesumawardani (2017) conducted a research about an analysis of subtitling strategies used in Wonder Woman Movie. She found based on 830 data for subtitling strategies, the most frequent used in the movie is transfer and the least is transcription.

Based on the phenomena of the journals also examples described above is the background that encourage the researcher to explain the reason of utilizing subtitling strategies in The Meg movie texts. The researcher used theory of the reason of subtitling strategy proposed by Dries (1995) namely historical circumstances, traditions and the strategy to which is accustomed for both the source and the target viewer.

Based on the problems of the study, the objective of this study is to explain the reason of utilizing subtitling strategies in The Meg movie texts.

\section{METHODOLOGY}

Based on the research study and theory, this research was conducted by using descriptive qualitative research method. The researcher used descriptive qualitative method because of some reasons. First, the data are clauses coming from documents or key 
informants. The data which have been gathered are described and suited with the aim of this study.

The data of this research are clauses of utterances reflecting subtitling strategies. The source of data in this research is parallel corpus consisting of spoken text spoken by fifteenth characters in The Meg Movie published in 8 August, 2018 as the source language (English) and Indonesian subtitling appear in the monitor as the target language (Indonesia) from the beginning part until the last of the movie. Roscoe (1975) stated that in qualitative research, if the population is less than 30 then all populations can be sampled. It means that from 15 characters in the movie, the researcher choose all characters in this movie to be analyzed in this research. The duration of the movie is 155 minutes. Those transcripts subtitling (source language and target language) elaborated into clauses classified into the reason of utilizing subtitling strategies by Dries's (1995).

\section{FINDINGS AND DISCUSSIONS}

Dries (1995) states at least three reasons behind the occurrences of subtitling strategies. They are historical circumstances, traditions and the strategy to which is accustomed for both the source and the target viewer.

\section{(1) Historical Circumstances}

The translator has a closer look at the division of countries according to type of screen translation they use and their influence on particular cultures in the country. In this case, the translator used some languages in target language based on culturally in the country used especially in Indonesia. It is called historical circumstances.

For instance:

Data 252

SL: I've got an emergency locator beacon 20 miles south southwest TL: Ada suar pencari darurat $32 \mathrm{~km}$ Selatan Barat Daya

Based on the data above, the clause of "I've got an emergency locator beacon 20 miles south southwest" of source language was translated into "Ada suar pencari darurat $32 \mathrm{~km}$ Selatan Barat Daya" in subtitles of target language. In this case, the translator chooses to converted unit of "miles" into " $\mathbf{k m}$ ". In Indonesia, the used of "miles" for measurement is not familiar language. It is for the distance used in Britain. So, in this case the translator converted the unit "miles" into " $\mathbf{k m}$ " in order to be acceptable in Indonesia culture itself. 
Data 273

SL: This tracker rifle only has a 100-foot range.

TL: Senapan pelacak ini hanya berjarak 30 meter

Based on the data 273 above, the clause of "This tracker rifle only has a 100-foot range" of source language was translated into "Senapan pelacak ini hanya berjarak 30 meter" in subtitles of target language. In this case, the translator chooses to converted unit of "feet" into "meter". In Indonesia, the used of "feet" for measurement is not familiar language. So, the translator converted the unit "feet" into "meter" in order to be acceptable in Indonesia culture.

(2) Traditions

The next reason is when the grammatical structures of source language do not exist in target language literally. For example, the position of the clause of replaying thanking in Indonesia which is not familiar in English sentences. Here, the subtitling strategy happened due to different linguistic system between source language and target language. The translator did this subtitling strategy to make the target language acceptable in tradition of region area. For instance:

Data 201

SL: You're welcome

TL: Terima kasih kembali

Based on the data 201 above, the clause of "You're welcome" was translated into “Terima kasih kembali” in subtitles of target language. Here, the translator translated “Terima kasih kembali" in target language to make it acceptable in tradition of certain region area.

Data 258

SL: These sharks have no fins

TL: Hiu-hiu ini tak punya sirip

Based on the data 258 above, the clause of "These sharks have no fins" was translated into "Hiu-hiu ini tak punya sirip" in subtitles of target language. Here, the translator translated the word of "have no" in source language into the meaning of "tak" in target language to make it acceptable in tradition of certain region area. The word of "tak" means "tidak" in some region area. 
Data 162

SL: I can't tell

TL: Entahlah

Based on the data 162 above, the clause of "I can't tell" was translated into "Entahlah" in subtitles of target language. Here, the translator translated the word "Entahlah" in target language to make it acceptable in tradition of certain region area. "Entahlah" is word to state or answers of do not know.

(3) The strategy to which is accustomed for both the source and the target viewer.

The last reason is translating the subtitle of movie not only concerns in the grammatical sentence but also in the utterances as close as possible with the source language in order to make a good and readable subtitle to the viewers based on the translator opinion related to the movie contexts.

For instance:

Data 82

SL: Hey, now you're only saying that because I literally have a beer in my hand TL: Kau bilang begitu karena ada bir ditanganku

Based on the data above, the sentences "Hey, now you're only saying that because I literally have a beer in my hand" of source language was translated into "Kau bilang begitu karena ada bir ditanganku" in subtitles of target language. In this case, the translators make it condense in target language because 38 characters in 1 row are the maximum number that the translator has to fulfill, no more and the subtitles must contain only 2 lines, no more. So, condensation, simplification and shortening of translations are needed to fulfill the subtitles in target language without changing the meaning.

Data 91

SL: Hey, I mean no offense, Doctor Zhang

TL: Jangan tersinggung Dr. Zhang

Data 91 above, "Hey, I mean no offense, Doctor Zhang" of source language was translated into "Jangan tersinggung Dr. Zhang” in subtitles of target language. In this case, the translators delete some part of words in source language because to make correlate in target language without lost the message.

Data 159 
SL: Tell her to get out of the way, Mac

TL: Suruh dia menyingkir, Mac

Data 159 above, "Tell her to get out of the way, Mac" of source language was translated into "Suruh dia menyingkir, Mac" in subtitles of target language. Paraphrase strategy is used by the subtitler to make the audience understand what messages are trying to convey by changing the difficult words into simple words which can be more easily understood by the audience without changing the meaning itself.

The findings mean that by stating that the results of these findings as an evidence that the types of subtitling strategies, actually that is not directly in use by the translator, in other words, this is really a proof that the subtitling strategies are very useful for this study and for further research, and where here it is very large use and affect both the researcher and the reader as an observer only.

And also it can be concluded that, after the result of this study, not only of the level of knowledge of the types of subtitling strategies that must be understood, but it can also increase our knowledge in understanding the contents of the language and hopefully in the next study will be further explored a more detailed analysis about subtitling strategies in another subtitles of the movie.

\section{CONCLUSIONS}

Based on the research findings, the conclusions was drawn that the reason behind the occurrences of subtitling strategies that used in The Meg Movie Texts based on Dries (1995). The first one is the translator used some languages in target language based on culturally in the country used especially in Indonesia. The next reason is when the grammatical structures of source language do not exist in target language literally, the translator did subtitling strategy to make the target language acceptable in tradition of region area and the last reason is the translator was translated the subtitles of movie not only concerns in the grammatical sentence but also in the utterances as close as possible with the source language in order to make a good and readable subtitle to the viewers based on the translators' opinion related to the movie context.

\section{REFERENCES}

Catford, J. C. 1965. A Linguistic Theory of Translation. London: Oxford University Press.

Dries, J. 1995. Dubbing and Subtitling: Guidelines for Production and Distribution. Düsseldorf, Germany. European Institute for the Media. 
Endang, D. H. 2015. An Analysis of Subtitling Strategies of Romeo and Juliet Movie.

Sumberlawang: Universitas Sumberlawang.

Gottlieb, H. 1997. Subtitles, Translation \& Idioms. Copenhagen: Centre for Translation Studies, University of Copenhagen.

J.T. Roscoe. 1975. Fundamental Research Statistic for the Behavioral Sciences. New York: Holt, Rinehart and Winston. Inc. pp.189

Kusumawardani, D. 2017. Analysis of Subtitling Strategies used in Wonder Woman Movie. Surakarta: Universitas Muhammadiyah Surakarta. 